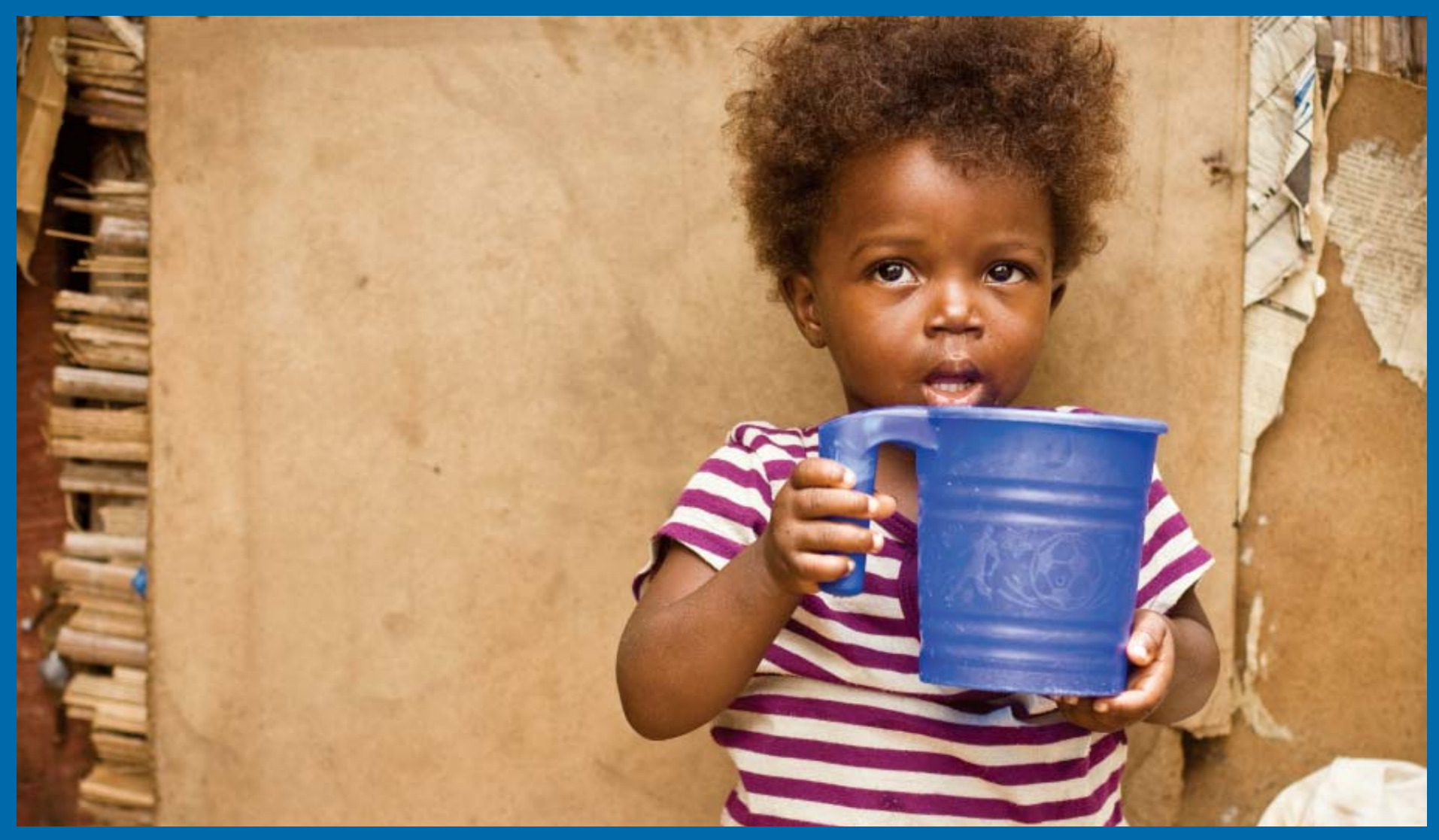

\title{
Foundation Funding for Water, Sanitation, and Hygiene
}

MARCH 2012 RESEARCH BRIEF

\section{\&ै WASHfunders.org}

\author{
A project of the
FOUNDATION CENTER
}




\section{Water, Sanitation, and Hygiene: A Global Crisis}

Worldwide, 780 million people do not have reliable access to clean water, and a staggering 2.5 billion, including nearly 1 billion children, do not have adequate sanitation. The repercussions are severe and far-reaching.

- Diseases from unsafe water and lack of basic sanitation kill more people every year than all forms of violence, including war. A major culprit is diarrheal disease, which is the second leading contributor to the global burden of disease-ahead of heart disease and HIV/AIDS. ${ }^{1}$

- In several sub-Saharan African countries, more than 25 percent of the population must travel more than $\mathbf{3 0}$ minutes to the nearest water source. ${ }^{2}$

- Lost productivity and increased health care costs take a heavy economic toll. Africa alone experiences economic losses of $\$ 28$ billion/year (or about 5 percent of GDP) due to lack of safe water and inadequate sanitation and hygiene. ${ }^{3}$

Changing this reality will require the collective effort of governments, corporations, non-profits, and organized philanthropy. This research brief takes a closer look at the role of foundation funding in addressing this global crisis.
U.S. FOUNDATION SUPPORT FOR WASH IS GROWING...

\begin{tabular}{lll}
\hline & 2003 & 2010 \\
\hline Number of & & \\
U.S. Foundations \\
Giving to WASH
\end{tabular}

Number of

Unique Recipient

Organizations

Percent of Foundations

Making More Than

One WASH Grant

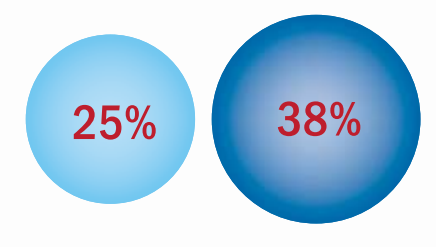

\section{Percent of Total}

International Giving by

$-0.2 \%$

$1.7 \%$

U.S. Foundations

\section{...BUT STILL MAKES UP A SMALL PORTION OF GIVING FOR INTERNATIONAL ISSUES.}

\section{U.S. FOUNDATION FUNDING FOR WASH: 2003-2010}

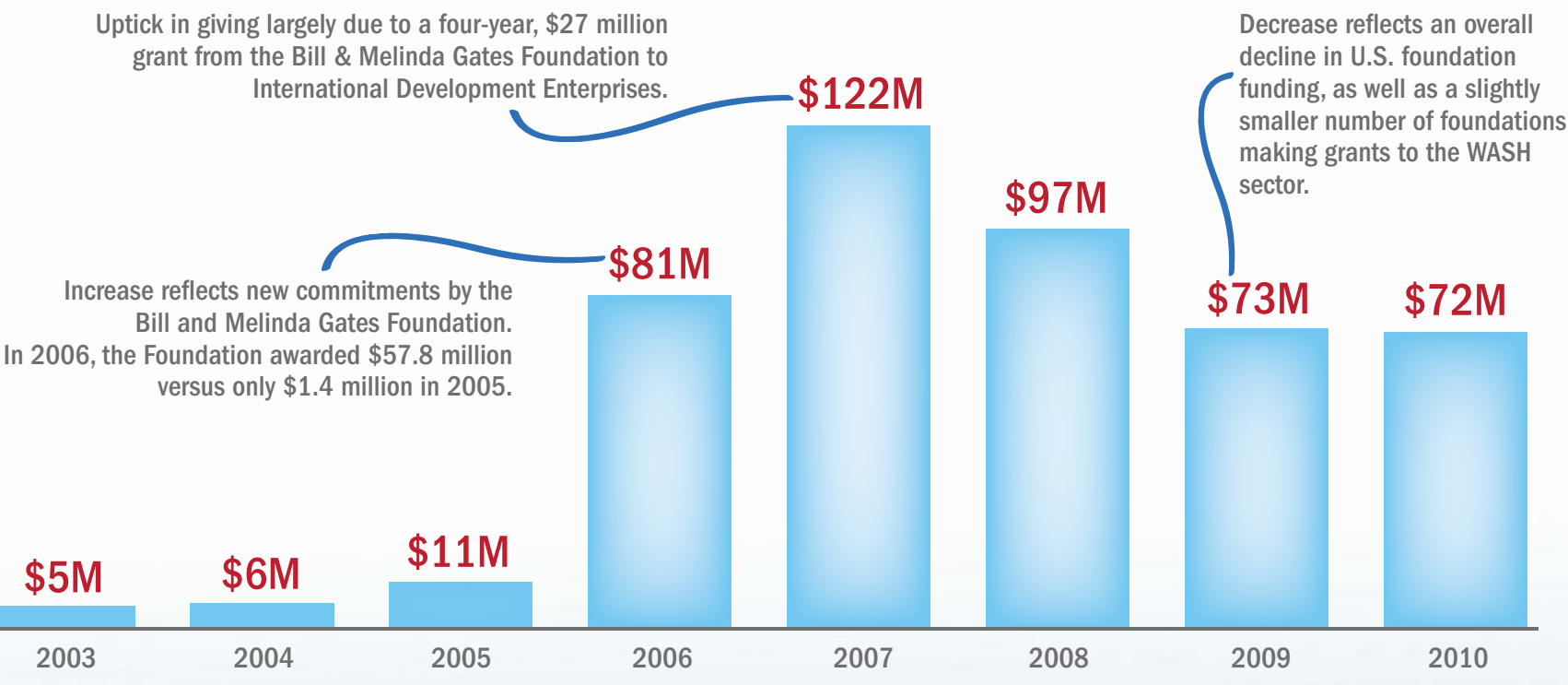




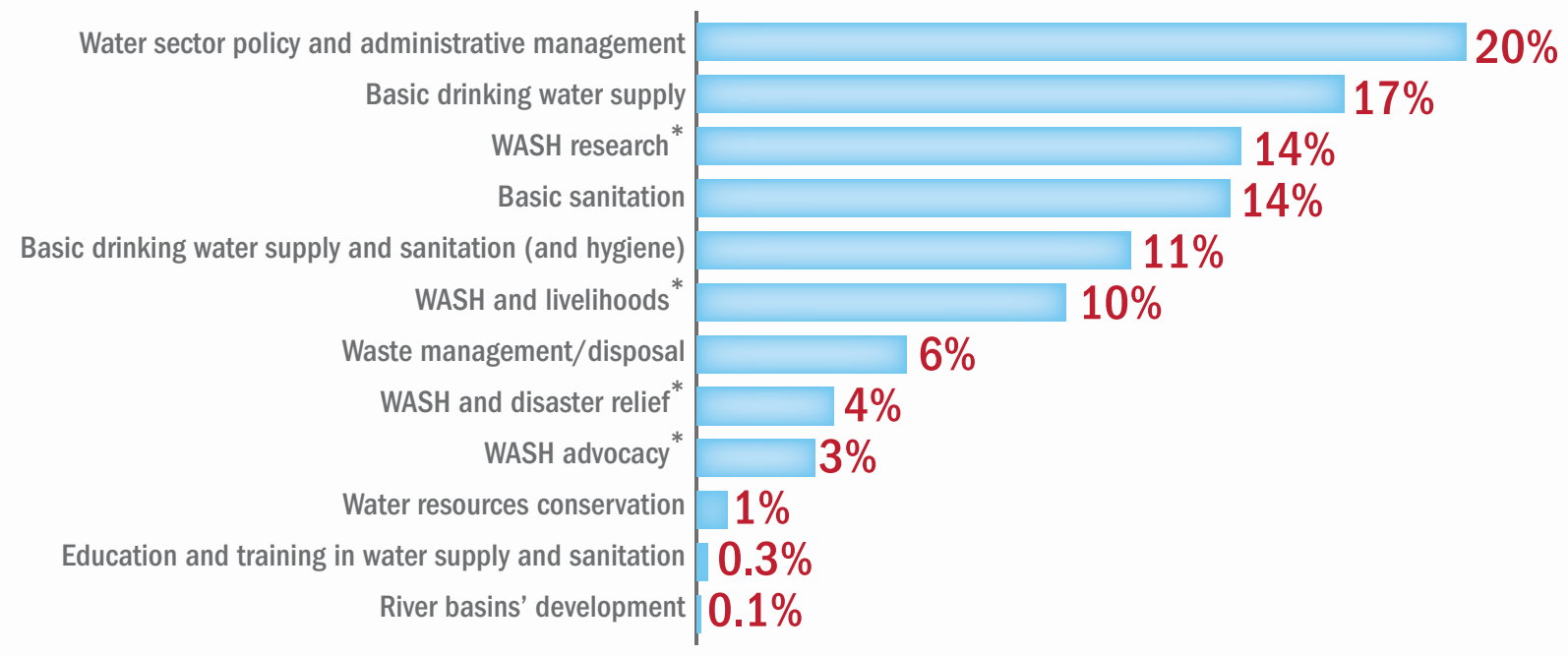

The Foundation Center's WASH-related taxonomy corresponds closely to the OECD taxonomy, which is used to classify bilateral and multilateral aid. However, because OECD categories do not fully capture the unique nature of foundation giving, several supplemental "foundation only" categories (noted with *) were created. Some grants encompass more than one category. To avoid doublecounting of grant dollars, only the primary subject area is represented. For definitions of each WASH category, visit the FAQ section of WASHfunders.org.

For more detailed information on foundation funding, visit WASHfunders.org. Launched in October 2011, WASHfunders.org includes an interactive funding map that displays grants information by country and subject area. Grants information is overlaid with key development indicators, such as access to water, as well as data on international aid funding.

TYPE OF SUPPORT, 2009-2010 (percent of grant dollars) 


\section{WASH Grantmaking by Country, 2009-2010}
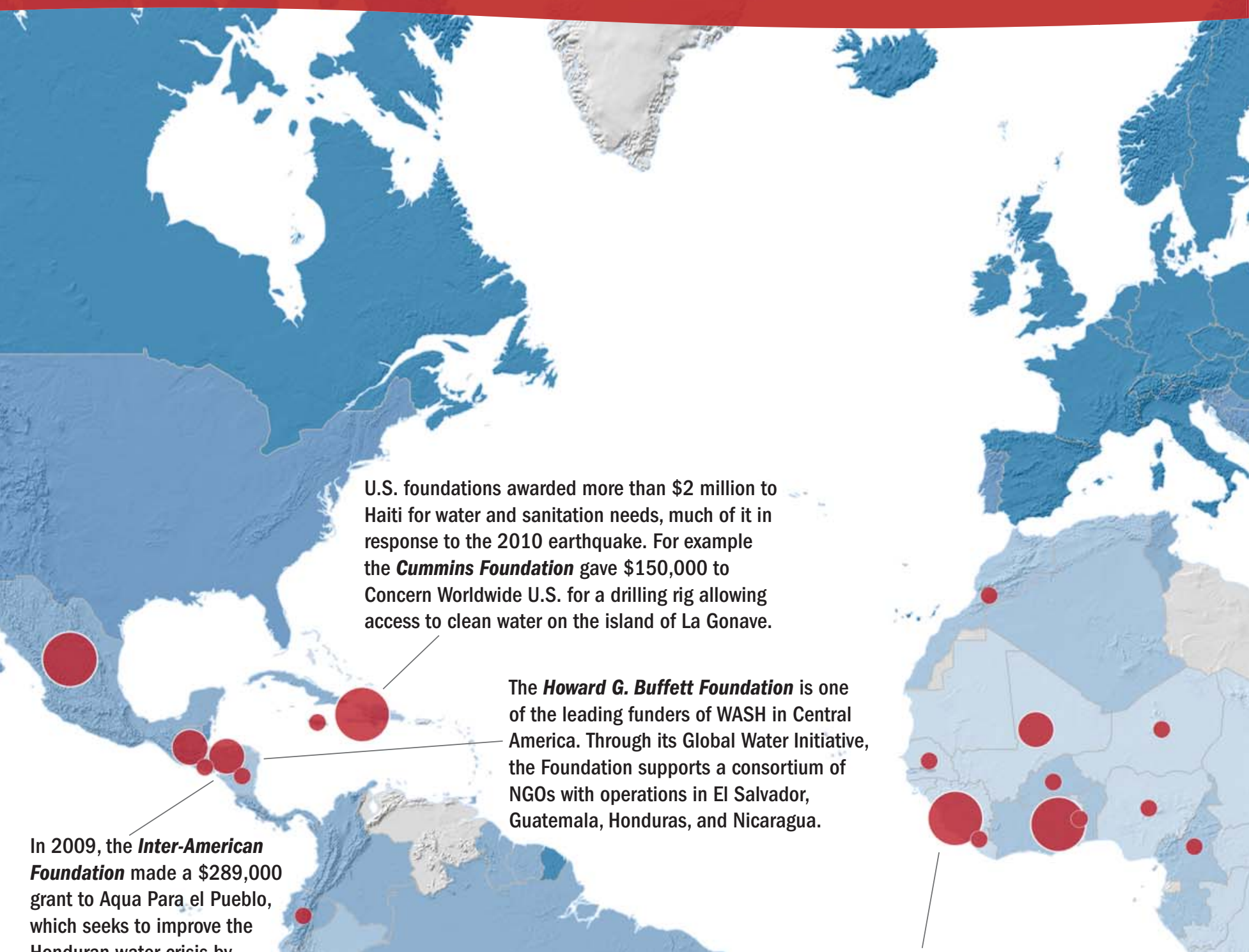

In 2009, the Inter-American Foundation made a $\$ 289,000$ grant to Aqua Para el Pueblo, which seeks to improve the Honduran water crisis by working with both indigenous communities and government officials.
The Howard G. Buffett Foundation is one of the leading funders of WASH in Central America. Through its Global Water Initiative, the Foundation supports a consortium of NGOs with operations in El Salvador, Guatemala, Honduras, and Nicaragua.

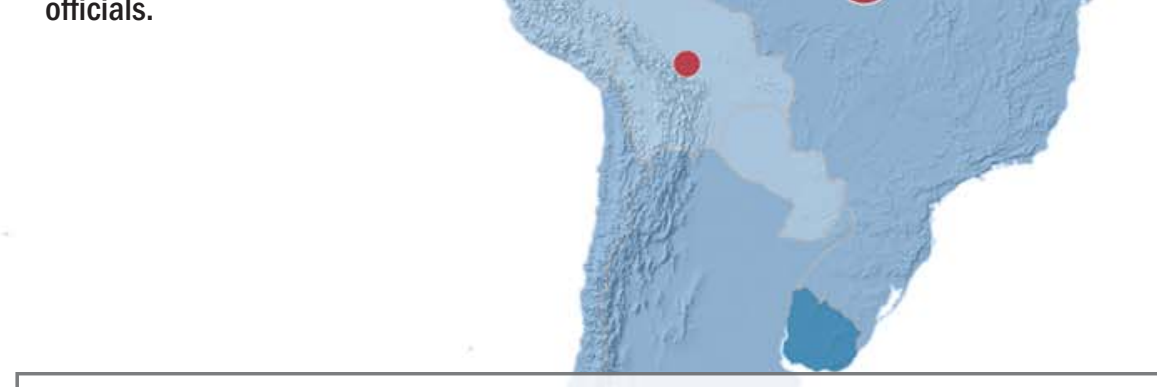

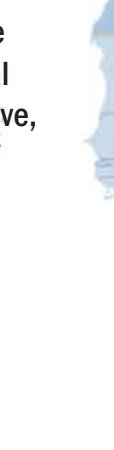

In 2009, Newman's Own Foundation awarded \$1.25 million to Safe Water Network to construct safe water kiosks and rainwater harvesting systems in Ghana, India, and Kenya.

\section{U.S. FOUNDATION FUNDING, 2009-2010}

\begin{tabular}{|c|c|c|c|c|c|}
\hline$\underset{\text { GRANT DOLLARS }}{\$ 144.2 \mathrm{M}}$ & $\begin{array}{l}348 \\
\text { GRANTS }\end{array}$ & $\begin{array}{c}41 \% \\
\text { GRANT DOLLARS } \\
\text { FOR DEVELOPING } \\
\text { COUNTRIES/ } \\
\text { GLOBAL PROGRAMS } \\
\text { (UNSPECIFIED) }^{1}\end{array}$ & $\begin{array}{l}30 \% \\
\text { GRANT DOLLARS } \\
\text { FOR AFRICA }\end{array}$ & $\begin{array}{c}18 \% \\
\text { GRANT DOLLARS } \\
\text { FOR ASIA }\end{array}$ & $\begin{array}{c}\mathbf{9 \%} \\
\text { GRANT DOLLARS } \\
\text { FOR CENTRAL/ } \\
\text { SOUTH AMERICA }\end{array}$ \\
\hline
\end{tabular}


-

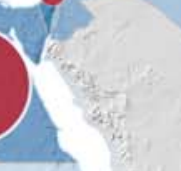

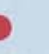

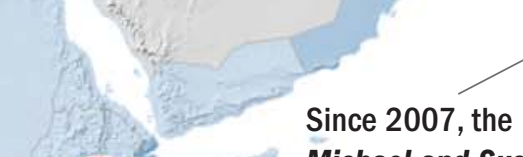

Michael and Susan Dell Foundation has awarded nine grants worth over $\$ 1.2$ million to India. Many of these grants focus on microfinance initiatives for urban slum dwellers.

The Conrad N. Hilton Foundation awarded $\$ 822,000$ to the Millennium Water Alliance in 2010 to support WASH programming in Ethiopia.

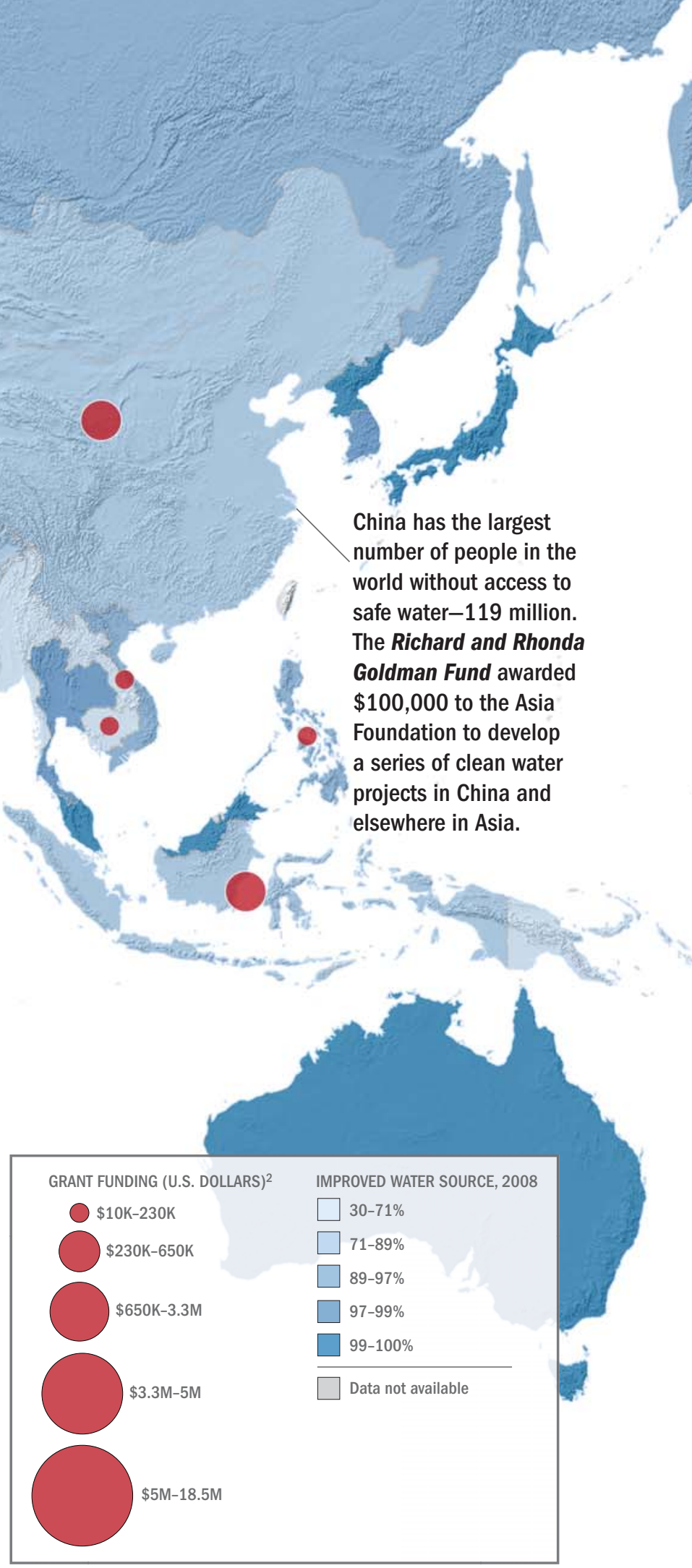


The Conrad N. Hilton

Foundation has supported

the WASH sector for

two decades, investing

more than $\$ 90$ million in

providing access to safe

water for nearly 2 million

of the world's poorest

people. In 2011, the

Foundation strengthened its commitment to safe water

with a five-year,

$\$ 50$ million initiative.

\section{In 2011, the Bill and}

Melinda Gates Foundation

launched its Reinvent the

Toilet Challenge, designed

to increase access to

sanitation, reduce diarrheal

disease, and improve the

lives of the world's

1.1 billion people who do

not have access to a toilet.

The Pepsico Foundation

has given nearly \$34 million

since $\mathbf{2 0 0 5}$ to combat

the global water crisis.

The Foundation's recent

$\$ 8$ million grant to

Water.org to scale the

WaterCredit initiative in

India was the largest award

in the Foundation's 50 year

history.

Several notable U.S.

foundations are embarking

on new grantmaking

initiatives related to WASH

including the Margaret A.

Cargill Foundation, the

Rockefeller Foundation,

and the Skoll Global

Threats Fund.
TOP FIVE PRIVATE FOUNDATIONS, 2009-2010

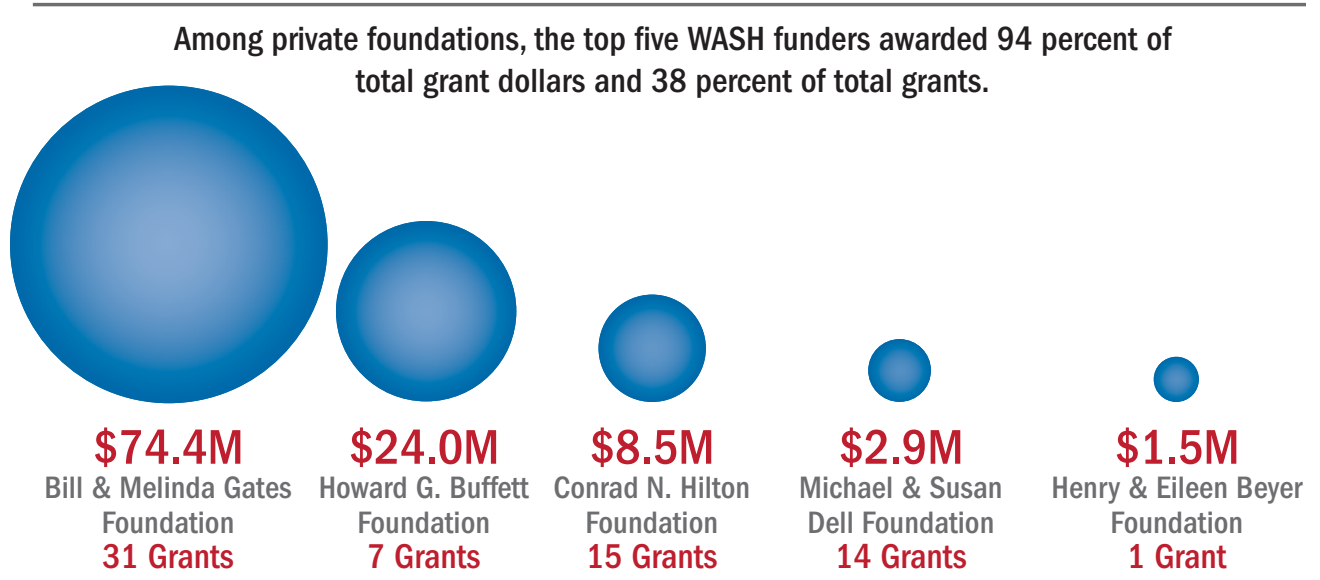

TOP FIVE CORPORATE FOUNDATIONS, 2009-2010

Among corporate foundations, the top five WASH funders awarded 88 percent of total grant dollars and 45 percent of total grants.

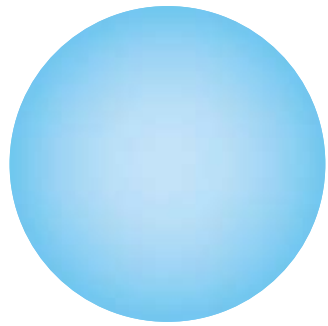

$\begin{array}{cccc}\$ 0.4 \mathrm{M} & \$ 0.5 \mathrm{M} & \$ 0.9 \mathrm{M} & \$ 1.3 \mathrm{M} \\ \text { Alcoa } & \text { Coca-Cola } & \text { NIKE } & \text { Newman's 0wn } \\ \text { Foundation } & \text { Foundation } & \text { Foundaton } & \text { Foundation } \\ 6 \text { Grants } & 3 \text { Grants } & 3 \text { Grants } & 2 \text { Grants }\end{array}$

$\$ 12.1 \mathrm{M}$

Pepsico

Foundation

8 Grants

TOP 10 RECIPIENTS, 2009-2010

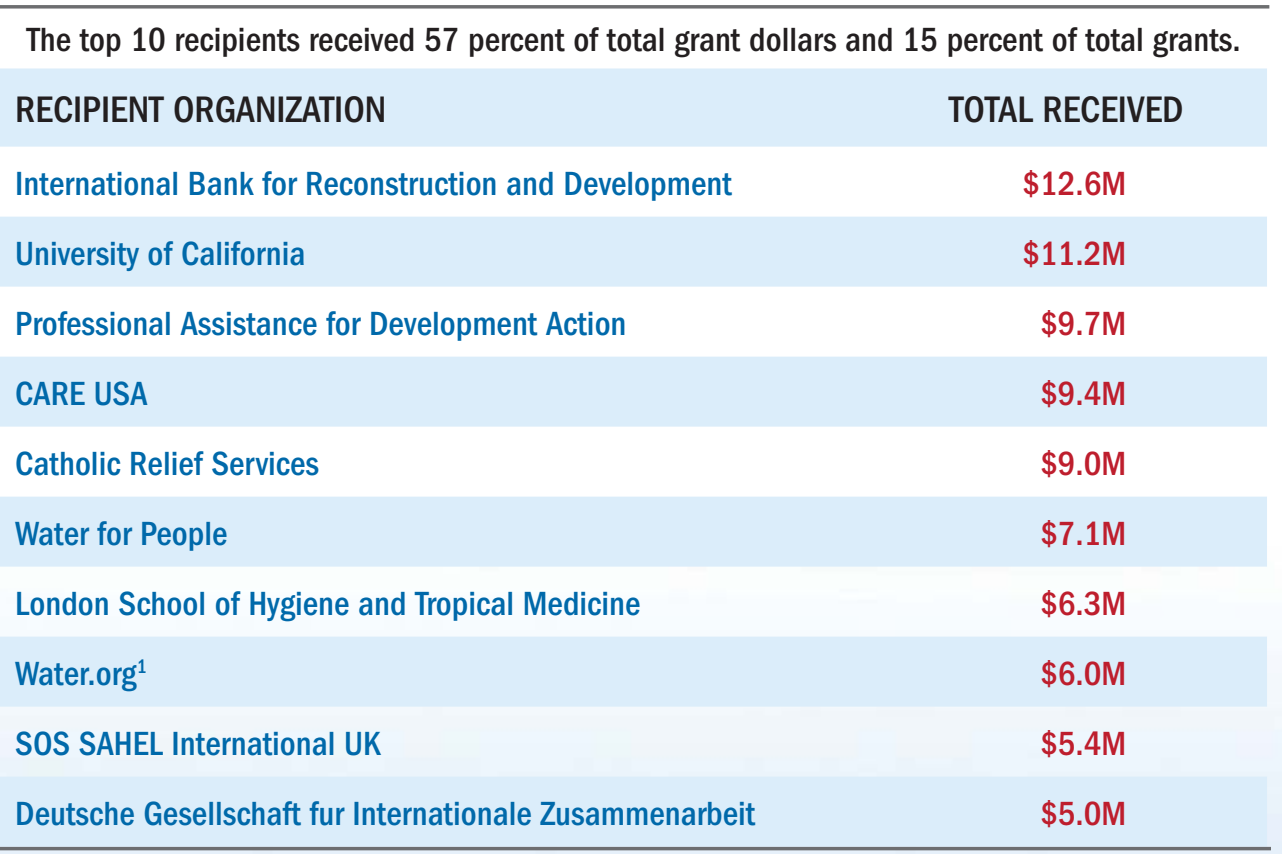

${ }^{1}$ WaterPartners International, founded in 1990, merged with H20 Africa in July 2009 resulting in the launch of Water.org. 


\section{Grantmaking by International Foundations}

The Foundation Center's database includes a growing number of foundations outside of the United States. While the Center's international data are not comprehensive, it shows a number of foundations active in WASH funding. In the coming year, the Foundation Center will be collecting new data on WASH grants from foundations outside of the United States. To submit grants information or share a lead, send an e-mail to washfunders@foundationcenter.org.

SELECT INTERNATIONAL FOUNDATIONS, 2007-2010

\begin{tabular}{lcccc}
\hline FUNDER & LOCATION & $\begin{array}{c}\text { TOTAL } \\
\text { GIVING }\end{array}$ & $\begin{array}{c}\text { NUMBER } \\
\text { OF GRANTS }\end{array}$ & $\begin{array}{c}\text { YEAR(S) OF } \\
\text { GRANT AWARDS }\end{array}$ \\
\hline Nationale Postcode Loterij & Amsterdam, Netherlands & $\$ 4.8 \mathrm{M}$ & 2 & 2009,2010 \\
\hline Arab Fund for Economic and Social Development & Kuwait & $\$ 1.2 \mathrm{M}$ & 2 & 2007 \\
\hline Pro Victimis Foundation & Geneva, Switzerland & $\$ 0.6 \mathrm{M}$ & 6 & 2009 \\
\hline King Baudouin Foundation & Brussels, Belgium & $\$ 0.5 \mathrm{M}$ & 14 & 2009,2010 \\
\hline Welfare Association & Multiple Locations ${ }^{1}$ & $\$ 0.5 \mathrm{M}$ & 1 & 2008 \\
\hline Starr International Foundation & Zurich, Switzerland & $\$ 0.3 \mathrm{M}$ & 1 & 2010 \\
\hline Oak Foundation & Geneva, Switzerland & $\$ 0.2 \mathrm{M}$ & 1 & 2009 \\
\hline Narada Foundation & Beijing, China & $\$ 0.1 \mathrm{M}$ & 5 & 2008,2010 \\
\hline
\end{tabular}

${ }^{1}$ The Welfare Association maintains offices in Geneva and multiple Middle Eastern locations.

\section{About the Foundation Center Grants Sample}

The data presented in this brief is based on the Foundation Center's grants set, which includes all grants of $\$ 10,000$ or more awarded to organizations by more than 1,000 of the largest U.S. foundations, including the top 15 funders in most states.

\section{Endnotes}

1. World Health Organization, UN-Water Global Annual Assessment of Sanitation and Drinking-Water (GLAAS) 2010: Targeting Resources for Better Results. (Switzerland: WHO Press, 2010): 11. whqlibdoc.who.int/publications/2010/9789241599351_eng.pdf

2. UNICEF and World Health Organization, Drinking Water: Equity, Safety and Sustainability. (USA: 2011): 28.

www.unicef.org/wash/files/JMP_Report_DrinkingWater_2011.pdf

3. UNESCO, United Nations World Water Development Report: Water in a Changing World. (UNESCO Publishing, 2009): 8.

unesdoc. unesco.org/images/0018/001819/181993e.pdf\#page=5

4. World Health Organization, UN-Water Global Annual Assessment of Sanitation and Drinking-Water (GLAAS) 2010: Targeting Resources for Better Results. (Switzerland: WHO Press, 2010): 30.

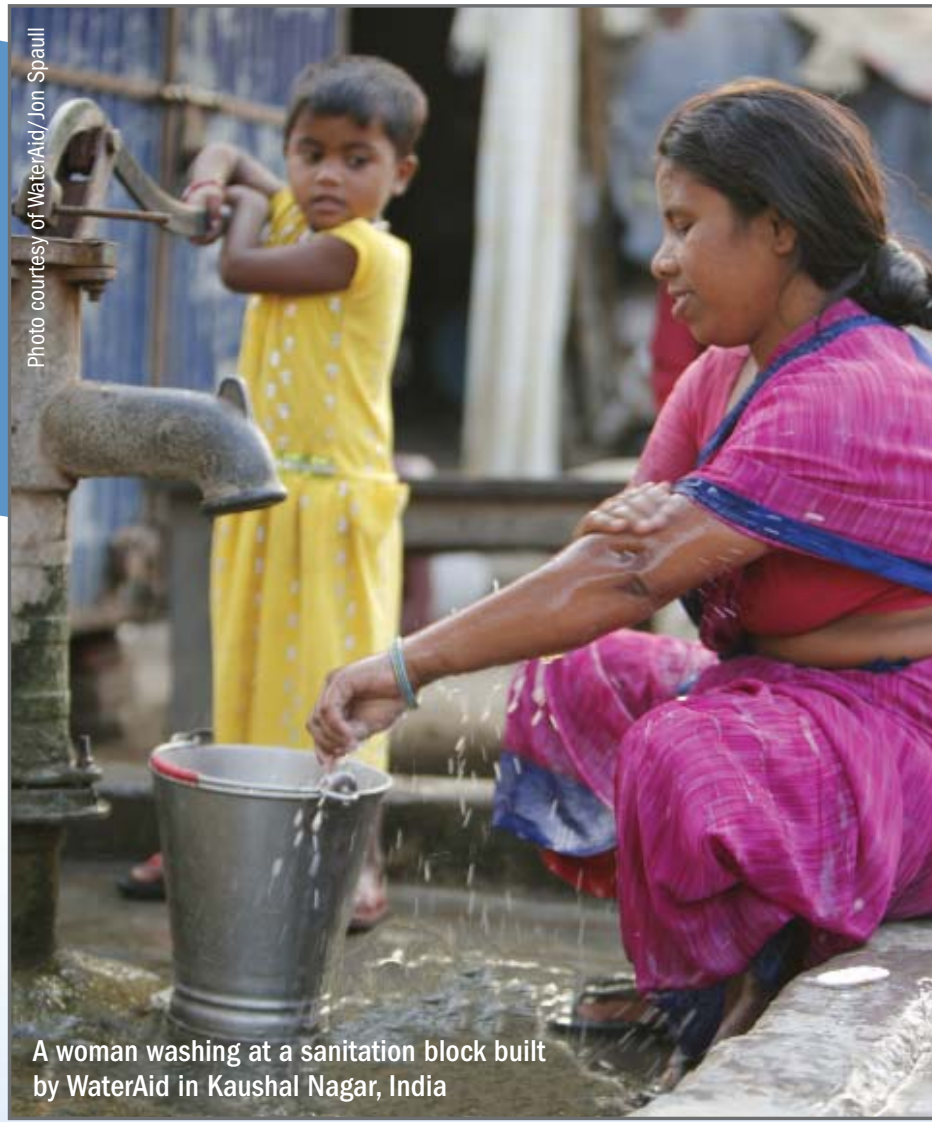




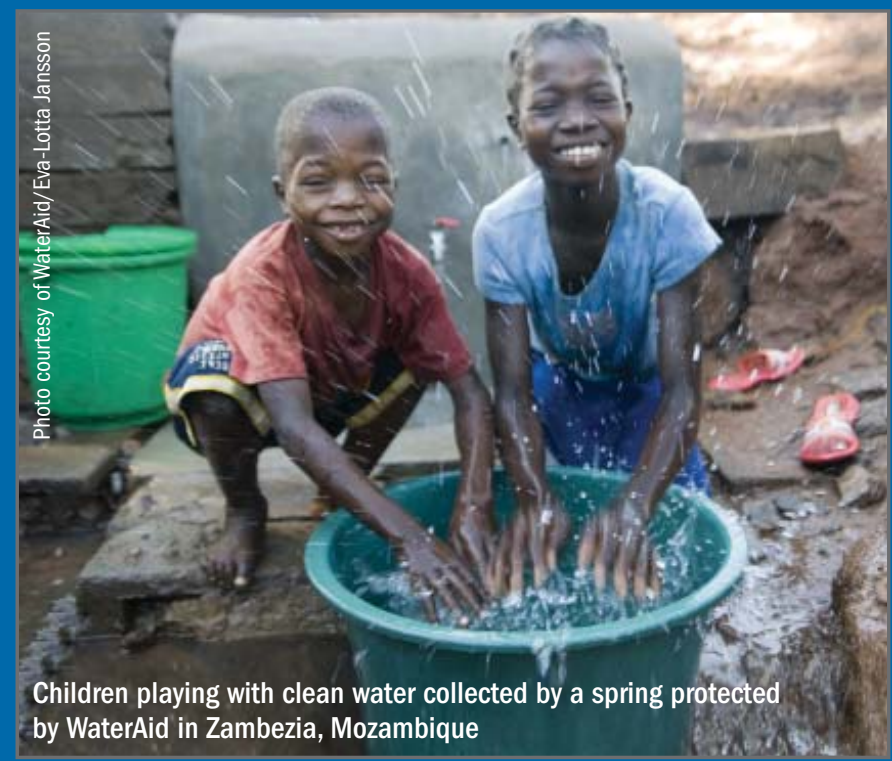

\section{About WASHfunders.org}

In October 2011, the Foundation Center launched WASHfunders.org, a web portal for funding and needs-related data for donors, policymakers, and other stakeholders interested in water, sanitation, and hygiene. With dynamically updated information, news, and knowledge relating to philanthropy and sustainable access to safe water, WASHfunders.org seeks to facilitate better collaboration and more strategic decision-making among funders and aims to raise awareness about water and the full WASH continuum among donors.

\section{About the Foundation Center}

Established in 1956, the Foundation Center is the leading source of information about philanthropy worldwide. Through data, analysis, and training, it connects people who want to change the world to the resources they need to succeed. The Center maintains the most comprehensive database on U.S. and, increasingly, global grantmakers and their grants-a robust, accessible knowledge bank for the sector. It also operates research, education, and training programs designed to advance knowledge of philanthropy at every level. Thousands of people visit the Center's web site each day and are served in its five regional library/learning centers and its network of more than 450 funding information centers located in public libraries, community foundations, and educational institutions nationwide and around the world. For more information, please visit foundationcenter.org or call (212) 620-4230.

Source for all data: The Foundation Center, Foundation Funding for Water, Sanitation, and Hygiene, 2012.

Download this report at foundationcenter.org/gainknowledge/ research/pdf/washfunders_brief_2012.pdf. For more information about this research brief or WASHfunders.org, please contact Seema Shah at sms@foundationcenter.org.

WASHfunders.org and this research brief are made possible through the generous support of the Conrad N. Hilton Foundation.

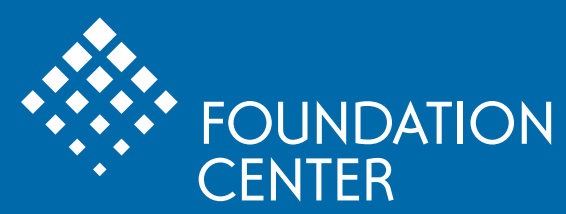

Knowledge to build on.

\section{Conrad N. Hilton} $F \bigcirc U N D A T I O N$ 